\title{
Butterfly Diversity: An Indicator for Environmental Health within Tarkwa Gold Mine, Ghana
}

\author{
Rosina Kyerematen ${ }^{1}$, Samuel Adu-Acheampong ${ }^{2}$, Daniel Acquah-Lamptey ${ }^{3}$, Roger Sigismund Anderson ${ }^{4}$, \\ Erasmus H. Owusu ${ }^{1} \&$ Jones Mantey ${ }^{5}$ \\ ${ }^{1}$ Department of Animal Biology and Conservation Science, University of Ghana, Legon, Ghana \\ ${ }^{2}$ Department of Agronomy, University for Development Studies, Nyamkpala-Tamale, Ghana \\ ${ }^{3}$ Faculty of Biology, Department of Ecology-Animal Ecology, Philipps University of Marburg, Marburg, \\ Germany \\ ${ }^{4}$ African Regional Postgraduate Programme in Insect Science, University of Ghana, Legon, Ghana \\ ${ }^{5}$ Gold Fields Ghana Limited, Tarkwa Mines, Tarkwa, Ghana \\ Correspondence: Samuel Adu-Acheampong, Department of Agronomy, University for Development Studies, P. \\ O. Box TL 1982, Nyamkpala- Tamale, Ghana. Tel: 233-548-527-193. E-mail: nanaakyampon@gmail.com
}

Received: June 26, 2018

doi:10.5539/enrr.v8n3p69
Accepted: July 12, 2018

Online Published: July 21, 2018

\begin{abstract}
Many human societies, rely on proceeds from mining of metals and fossil fuels for income generation as well as resource supplies from biodiversity. However, these mining activities are in conflict with and threaten the sustainable utilisation and conservation of biodiversity. We used butterflies, a known bioindicator species as surrogates to measure the level of change in vegetation within Tarkwa Gold Mines (TGM) in Ghana. Butterfly assemblages were sampled within the concession and characterised in terms of diversity indices and vegetation type. Transect counts, aerial netting and charaxes trapping were employed to assess butterfly assemblages. Results showed that although there were high records of degraded forest and savanna indicator species, the fairly high presence of deep forested species also shows that some forested areas within the concession are still in good condition. Recommendations are made to maintain forest blocks to serve as refugia for butterflies and urge management to institute measures to restore old and abandoned mined sites. We also recommend policy makers to enact laws that will ensure that, mining organisations lay down plans for sustainable mine operations and biodiversity conservation before being granted licenses to operate in Ghana.
\end{abstract}

Keywords: butterflies, diversity, environment, mining, vegetation

\section{Introduction}

Mining of precious metals such as gold and silver and fossil fuel has been an illustrious venture for many countries especially developing ones. Not only do mining industries generate income to boost economies of such developing countries, they also create several employment opportunities for people (Akabzaa \& Darimani, 2001; Schueler, Kuemmerle, \& Schröder, 2011; Kitula, 2006). In spite of these benefits, mining also has some negative impacts on the environment. It has both direct and indirect effects on the environment and biodiversity (Lenzen, Murray, Korte, \& Dey, 2003). Mining directly removes fragments from the natural environment such as soil fertility and natural habitats. (Edwards et al., 2014; Kitula, 2006). For example, over $70 \%$ of the total land surface of Tarkwa has been cleared (Akabzaa \& Darimani, 2001), leading to the loss of $58 \%$ of forested areas as well as $45 \%$ of farmlands (Schueler et al., 2011). Mining companies within and around Tarkwa use between 40 to $60 \%$ of their total concession space for mine activities such as road construction, tailings dump, open pits etc. and the rest maybe used for biodiversity conservation (Akabzaa \& Darimani, 2001). This has impacted significantly on the main vegetation and natural resource capital within Tarkwa and its environs and also impacted on the livelihood of people including loss of farm lands and a reduction in food production as reported by Attuquayefio et al. (2007) and Schueler et al. (2011). In addition, there is a general reduction in soil fertility to support agricultural production as well as loss of key habitats that support fauna such as birds, reptiles, mammals and invertebrates (Attuquayefio et al., 2007, Attuquayefio, Owusu, \& Ofori, 2017). Furthermore, some water bodies and wetlands are also destroyed through chemical pollution from mining activities (Akabzaa \& Darimani, 2001; Yelpaala \& Ali, 2005; 
Attuquayefio et al., 2007). Some of the main mine pollutants in Tarkwa and surrounding areas are mercury and oil release into water bodies (Attuquayefio et al., 2007; Schueler et al., 2011). Mercury pollutants and sediments from gold extraction that end up in water bodies, severely affect the species diversity of both aquatic fauna and flora (Brosse, Grenouillet, Gevrey, Khazraie, \& Tudesque, 2011); Jones, 2013). These pollutants bio-accumulate in animals especially fishes and other organisms which are eaten by humans. Mining also impacts on the environment and biodiversity through climate impacts (Yabe, Ishizuka, \& Umemura, 2010; Brosse et al., 2011).

The Tarkwa Gold Mine and its surrounding mines contribute 30 percent of the total Gold mined in Ghana (Akabzaa \& Darimani, 2001). Also, Tarkwa and its surrounding mines have the highest mine concentration in Ghana and the West African sub-region with 8 out of the 16 large mining companies in Ghana (including TGM). This area also has the only manganese mine in Ghana (Akabzaa \& Darimani, 2001). Because of the presence of heavy mining activities in Tarkwa, the issue of environmental pollution has become a major problem confronting the industry and communities involved as has been the case elsewhere (Amankwah \& Anim-Sackey, 2003; Attuquayefio et al., 2007; Hilson et al., 2007). To regulate activities and mitigate the environmental impacts of mining in Ghana, the government passed the Environmental Assessment Regulations Act in 1999, which is supervised by the Environmental Protection Agency (EPA, Ghana). It is anticipated that mine-related developments will be regulated through the act to ensure that the removal of surface vegetation from active parts of mine concessions are done sustainably through monitoring and at lessor cost to the environment and biodiversity.

Biodiversity assessment is one of the methods that has been employed as part of implementation of environmental impact assessment within the Tarkwa Gold Mine concession. We selected butterflies as surrogates to use as a bioindicator group to measure the impact of the mine activities on the environments and on biodiversity within the concession. Bioindicators are very sensitive organisms whose response within an environment (especially change in conditions) provides a more general information on environmental quality (Fleishman \& Murphy, 2009). Although, a chosen bioindicator might not show the same response that every other organism within an environment will react to, the response it gives provides a general idea of conditions within the system under consideration.

Some other animal groups that can be used as biondicators within the concession are insects such as grasshoppers (Hao, Wang, Cease, \& Kang, 2015; Adu-Acheampong, Bazelet, \& Samways, 2016, Adu-Acheampong et al., 2017), dragonflies (Lee Foote \& Rice, 2005; Acquah-Lamptey, Kyerematen, \& Owusu, 2013), butterflies (Maes \& Van Dyck, 2005; Bonfantti, Di Mare, \& Giovenardi, 2009, Van Dyck, Van Strien, Maes, \& Van Swaay, 2009; Hiyama, Taira, Sakauchi, \& Otaki, 2018) and ants (Majer, Orabi, \& Bisevac, 2007, Coelho, Fernandes, Santos, \& Delabie, 2009). Insects are mainly used as indicators of environmental degradation as well as bioindicators of the wellbeing of ecosystems (Acquah-Lamptey et al., 2013, Kyerematen, Owusu, Acquah-Lamptey, Anderson \& NtiamoaBaidu, 2014a; Kyerematen, Kaiwa, Acquah-Lamptey, Adu-Acheampong \& Andersen, 2018). They are critical natural resources in ecosystems, particularly those of forest origin (Raina, Chauhan, Tayal, Pande, \& Mohan, 2011). Insects are known to be very good bioindicators because they have relatively short life cycles, and consequently, respond rapidly to changes in environmental conditions. Their general life cycles are quite well-known and hence can also be easily related to changes in the environment (Weisser \& Siemann, 2008). One such insect group is the butterflies which provide information on the health of ecosystems through species presence-absence and abundance, hence, we used them as bioindicators to monitor changes in habitat conditions within the concession (Weisser \& Siemann, 2008; Bakowski \& Doku-Marfo, 2009; Kyerematen et al., 2018).

Butterflies are some of the most important insect groups known for being active during daytime with colourful wings which gives them considerable appeal and aesthetic value. There are close to 20,000 species of butterflies described worldwide, with about 4000 of them within Africa. (Larsen, 1994, 2006). The butterflies of West Africa, especially that of Ghana are fairly well studied compared to other regions in Africa although there is still enormous untapped knowledge on this group in Africa (Larsen, 2005, 2006; Nganso, Kyerematen, \& Obeng-Ofori, 2012; Bossart \& Antwi, 2013, 2016; Kyerematen et al., 2014a; Kyerematen, Acquah-Lamptey, Owusu, Anderson, \& Ntiamoa-Baidu, 2014b; Kyerematen, Akuamoah-Boateng, Acquah-Lamptey, \& Anderson, 2014c; Maes \& Van Dyck, 2005; Weisser \& Siemann, 2008). Currently there are about 925 described butterfly species in Ghana, with thousands of undescribed ones (Larsen, 2006). Butterflies have been used beneficially as biondicators to study the health of forest ecology in natural, managing and degraded ecosystems in the past (Wilson, 1987; Weisser \& Siemann, 2008; Bakowski \& Doku-Marfo, 2009; Gandhi, Patel, \& Padate, 2017). This is largely because members of this group show diversity of relative sensitivity to environmental change (Hawksworth \& Bull, 2007). They are also tightly intertwined with ecological systems as both primary consumers (herbivores) and food items with a fairly well known taxonomy, life history traits, high reproduction rate and a relatively small size (Nganso et al., 2012; Gandhi et al., 2017). The abundance and diversity of butterfly species in an ecosystem can be used as 
bionidicator for measuring the health of that environment (Weisser \& Siemann, 2008; Kyerematen et al., 2014a, b). For instance, the diversity and abundances of butterfly species have been used to access the impact of human activities on the landscape, rapid biodiversity assessment, monitoring degraded and managed ecosystems (Wilson, 1987; Maes \& Van Dyck, 2005; Weisser \& Siemann, 2008; Bakowski \& Doku-Marfo, 2009; Van Dyck et al., 2009; Gandhi et al., 2017; Kyerematen et al., 2018). This is because, their presence, absence, diversity and abundance have a direct correlation with ecosystem changes (Thomas \& Harrison, 1992; Pullin, 1996; Pollard et al., 1998; Van Dyck et al., 2009; Gandhi et al., 2017).

We carried out this research to assess biodiversity of butterflies within the mining concession to determine the species composition in key habitats that have been impacted by mining and related activities as well as nonimpacted ones. Our hypothesis for this research was that, mining and other related activities within the TGM concession impact negatively on butterfly diversity. Since the vegetation zone within which the gold mine is located falls within a wet and moist evergreen vegetation zone, we expect a significantly high diversity of species known to be associated with the wet and or moist evergreen tropical forests compared with few others known to be associated with dry Guinea or Sudan savannah zones in case there is little or no negative impact of mining on biodiversity. On the other hand, a significantly high diversity of species known to be associated with dry Guinea or Sudan savanna vegetation will be an indication of the negative impact of mining activities within the concession. In view of this, we expected significant differences between these two groups of species with the former being significantly higher compared to the latter group. If there are no significant differences between these two groups, it shows that the vegetation at TGM is changing from its original state that accommodates the latter group of species. This signifies a high level of degradation within the concession. Findings from this survey would be essential as it would serve as the first approach of using butterflies as part of indicator tools for subsequent monitoring and assessment of the ecological quality within the Tarkwa Gold Mining concession and its surrounding mines.

\section{Materials and Methods}

\subsection{Sampling Sites}

Tarkwa Gold Mine (TGM), is about $4 \mathrm{~km}$ west of Tarkwa within the Tarkwa-Nsuaem Municipal Assembly in the Western Region of Ghana. Tarkwa Gold Mine lease operation operates under seven gold mining leases and covers a total area of approximately 20,825 hectares. TGM concession falls within the interface of the Wet Evergreen and the Moist Evergreen Vegetation zones (Hall \& Swaine, 1976; Akabzaa \& Darimani, 2001). It is in south-western Ghana near the southern end of the Tarkwa Basin, approximately $300 \mathrm{~km}$ west of Accra at latitude $5^{\circ} 15^{\prime} \mathrm{N}$ and longitude $2^{\circ} 00^{\prime} \mathrm{N}$.

The mine is located within the south-western equatorial climatic zone and has a moist tropical climate. Temperature and rainfall are relatively high throughout the year and records annual averages of around $28^{\circ} \mathrm{C}$ and $1,927 \mathrm{~mm}$ respectively. The peak rainfall months are March to July and September to November.

Vegetation within the Tarkwa Mine concession comprises of a mosaic of secondary forests, regenerated and revegetated areas interspersed with mining facilities. The topography is generally undulating with isolated hills and ridges separated by valleys. Elevations measured during the survey ranged from $74 \mathrm{~m}$ to $213 \mathrm{~m}$ above mean sea level (amsl). The landscape is heavily modified by opencast mining with significant impact on the topography because of removal of hills, creation of lakes/ponds from excavated pits, creation of hills from deposition of waste rocks and infilling of valleys. The entire mining concession of TGM of GFGL was divided into three areas for sampling purposes for this work. Namely: North, Central and Southern divisions (see fig. 1). North Division: TSF 5 Project site - it is a disturbed lowland forest with a seasonally inundated swamp. TSF 3/Abrewanko stretch early succession secondary forest with forbs, farmland and bushes. TSF 1/ Training school stretch of vegetation with dense undergrowth, wetland within. Old Weighing Bridge - disturbed secondary forest with dense undergrowth. Abekoase Area - wetlands, ponds with surrounding vegetation. TSF 3 - Nuamakrom, Aunty Gladys Stretch - early succession secondary forest with forbs, large farm and bush lands. Back of Phase 5 Heap Leach Facility - savanna thicket with sparsely occurring emergent trees with a river flowing through. Back of Training School - natural upland forest with dense undergrowth and a stream flowing through, which is also the location for a water treatment facility. Central Division: TSF2/AEL/Dispatch/Kottraverchy stretch of vegetation - late succession secondary forest with few emergent trees, a wetland occurs within the area. Kottraverchy/Akontansi gap stretch - wetland within a disturbed forest on a hill slope. Bamboo Dump - reclaimed site with mixed stands of exotic and natural regenerating forest.

South division: South LV road vegetation stretch - mature secondary forest on a slope constructed mainly from waste rocks. TSF 4 stretch - disturbed mature secondary forest on low hilltop. *Assay lab stretch of vegetation - 
degraded wet evergreen forest on a low hill. *SP2 catchment pond vegetation stretch - late succession secondary forest. ${ }^{*}$ GAG boundary stretch - relic patch of good multi - storey wet evergreen forest. ${ }^{* *}$ South heap leach facility - relic patch of good multi - storey WE forest. ***Wetlands - mixed stands of naturally regenerating area around a large river/wetland. *** Old west heaps (Reclaimed site) - Mixed stands of exotic and natural regenerating vegetation $\{$ Sites having the same number of $(*)$ were sampled together as one area. (All TSFs occur along a Tailings Storage Facility)\}.

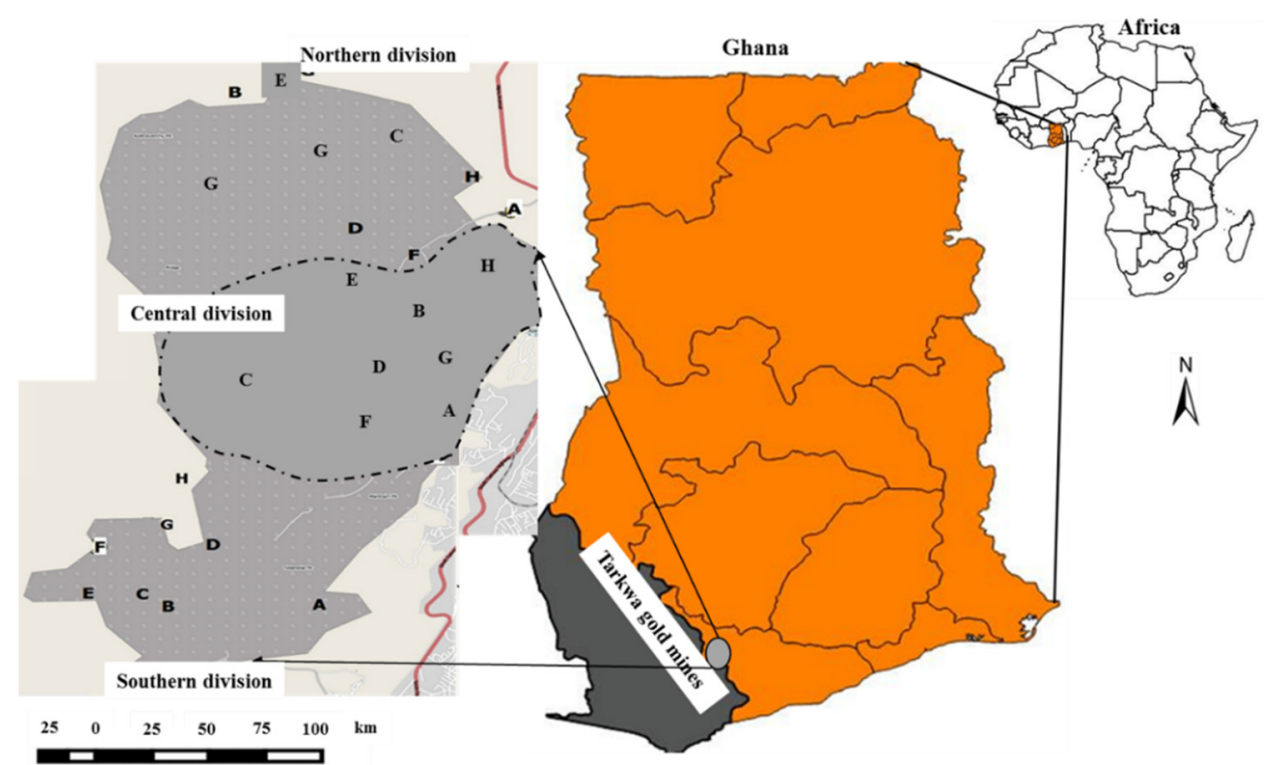

Figure 1. Map of Tarkwa Gold Mine (TGM) concession showing the locations of northern, central and southern divisions for this study

Table 1. Summary of type and environmental impact scale of sampling sites in Tarkwa Gold Mine

\begin{tabular}{lll}
\hline Name of site & Type of site & Environmental impact scale \\
\hline TSF1 & Secondary forest & Fair impact \\
KAG & Re-vegetated forest & Fair impact \\
TSF3 & Secondary forest & Fair impact \\
TSF4 & Secondary forest & High impact \\
TSF5 & Secondary forest & High impact \\
OWB & Secondary forest & High impact \\
ABE & Secondary forest & Fair impact \\
BOP5 & Secondary forest & Fair impact \\
BOTS & Secondary forest & Fair impact \\
AEL & Secondary forest & Fair impact \\
BAM & Re-vegetated forest & Fair impact \\
LV & Re-vegetated forest & Low impact \\
GAG & Secondary forest & Low impact \\
ATS & Residential area & High impact \\
WOWH & Secondary forest & Low impact \\
SP2 & Secondary forest & High impact \\
ABER & Secondary forest & Fair impact \\
\hline
\end{tabular}

ABE - Abekoase, TSF3 - Nuamakrom/Auntie Gladys, ABER - TSF3/Aberewanko, BOTS - Back of training school, BOP5 - back of phase 5/Samanhu, OWB - Old weighing bridge, KAG - Kottraverchy Akontansi gap, AEL - AEL Konttraverchy stretch, BAM - Bamboo dump, SP2 - SP2 assay lab, WOWH - Wetlands at old west heaps, GAG/SHL - south heaps GAG stretch, LV - South LV, ATS - Residential ATS.

\subsection{Butterfly Sampling}

Butterflies were sampled using Charaxes traps ( 8 " diameter circular wire frames, 18" - 20" net lengths), butterfly/aerial nets ( $38 \mathrm{~cm}$ diameter and $92 \mathrm{~cm}$ length), visual observations and approximately 100 - metre transect walk-and-counts. Alcohol - loving butterflies, as well as those attracted to fermenting foods, were sampled using 
Charaxes traps, five of which (one per site) were set up at each site. Each study location was divided into 5 sampling sites. Sampling was conducted on $85(17 \times 5)$ sites in total. Mashed rotten bananas mixed with beer was used as bait for the Charaxes traps. Each of these Charaxes traps were checked and restocked each morning when necessary. Efforts were made to select close to uniform sampling sites as possible. The smallest inter-site distance within an area of study was $50 \mathrm{~m}$ with the largest inter-site distance being $250 \mathrm{~m}$. Each sampling event lasted three hours, twice each day using random walk by three persons in each site. Each of the sampling sites was visited on four occasions. Field collections were carried out in August 2014 and February 2015 to capture both the wet and dry seasons. Butterfly identification was done with reference to Museum collections from the Department of Animal Biology and Conservation Science, University of Ghana, Carcasson (1981), Carter (1992), Chinery (1995), Larsen (2005), and all taxonomic names were verified according to Larsen (2006).

\section{Data Analysis}

Qualitative assessment of sites was done by comparing their diversity indices (Magurran, 2004) which were treated as bioindicators for biodiversity assessment (Marshall, Steward, \& Harch, 2006). Species accumulation curves as well as species richness estimators (Chao 1 and 2, Jacknife 1 and 2 and Bootstrap), based on 999 randomisations were also computed as a measure of sampling efforts in Primer-E software (Clarke \& Warwick, 2001; Clarke \& Gorley, 2006). One-way ANOVA was used to determine differences in butterfly diversity between species known to be associated with moist or wet evergreen forests on one side and dry semi-deciduous and marginal Forests, Guinea, and Sudan Savannah on the other side using Kruskal-Wallis test conducted in Statistica 13.2 (StatSoft, 2013). This analysis was done for the entire collection from the study after a Shapiro Wilk's test of normality had shown that the data was non-normally distributed (Kruskal-Wallis test: $\mathrm{H}=1.13 \mathrm{p}=0.29)$ (Hill \& Lewicki, 2007, StatSoft, 2013).

\section{Results}

A total of 1573 individual butterflies belonging to 93 species were recorded for the study.

Table 2. Butterfly species assemblage within Tarkwa Gold mine

\begin{tabular}{|c|c|c|c|c|}
\hline Butterfly family & Butterfly species & Habitat type & Abundance & No. of Sampling sites \\
\hline \multirow{25}{*}{ Nymphalidae } & Euphaedra sarcoptera & $\mathrm{EF}$ & 5 & 4 \\
\hline & Euphaedra harpalyce & ALF & 3 & 2 \\
\hline & Euphaedra medon & ALF & 5 & 2 \\
\hline & Euphaedra xypete & $\mathrm{EF}$ & 4 & 3 \\
\hline & Euphaedara eupalus & $\mathrm{EF}$ & 3 & 2 \\
\hline & Euphaedra crockeri & $\mathrm{EF}$ & 4 & 3 \\
\hline & Euphaedra themis & $\mathrm{DF}$ & 2 & 2 \\
\hline & Euphaedara edwardsi & ALF & 1 & 1 \\
\hline & Euphaedra janetta & ALF & 2 & 2 \\
\hline & Eurytela dryope & $\mathrm{DF}$ & 2 & 2 \\
\hline & Euriphene barombina & ALF & 9 & 6 \\
\hline & Euriphene simplex & $\mathrm{EF}$ & 5 & 3 \\
\hline & Pseudoacrea eurytus & ALF & 79 & 14 \\
\hline & Pseudoacrea lucreta & ALF & 66 & 12 \\
\hline & Pseudoneptis bugandensis & ALF & 4 & 4 \\
\hline & Neptis melicerta & $\mathrm{EF}$ & 33 & 8 \\
\hline & Neptis metella & ALF & 23 & 9 \\
\hline & Neptis merosa & DF & 15 & 8 \\
\hline & Protogoniomorpha anacardii & $\mathrm{DF}$ & 1 & 1 \\
\hline & Junonia terea & ALF & 21 & 7 \\
\hline & Junonia oenone & ALF & 24 & 6 \\
\hline & Phalanta phalantha & ALF & 3 & 2 \\
\hline & Ariadne enotera & ALF & 24 & 5 \\
\hline & Aterica galene & ALF & 4 & 3 \\
\hline & Byblia anvatara & ALF & 18 & 7 \\
\hline
\end{tabular}




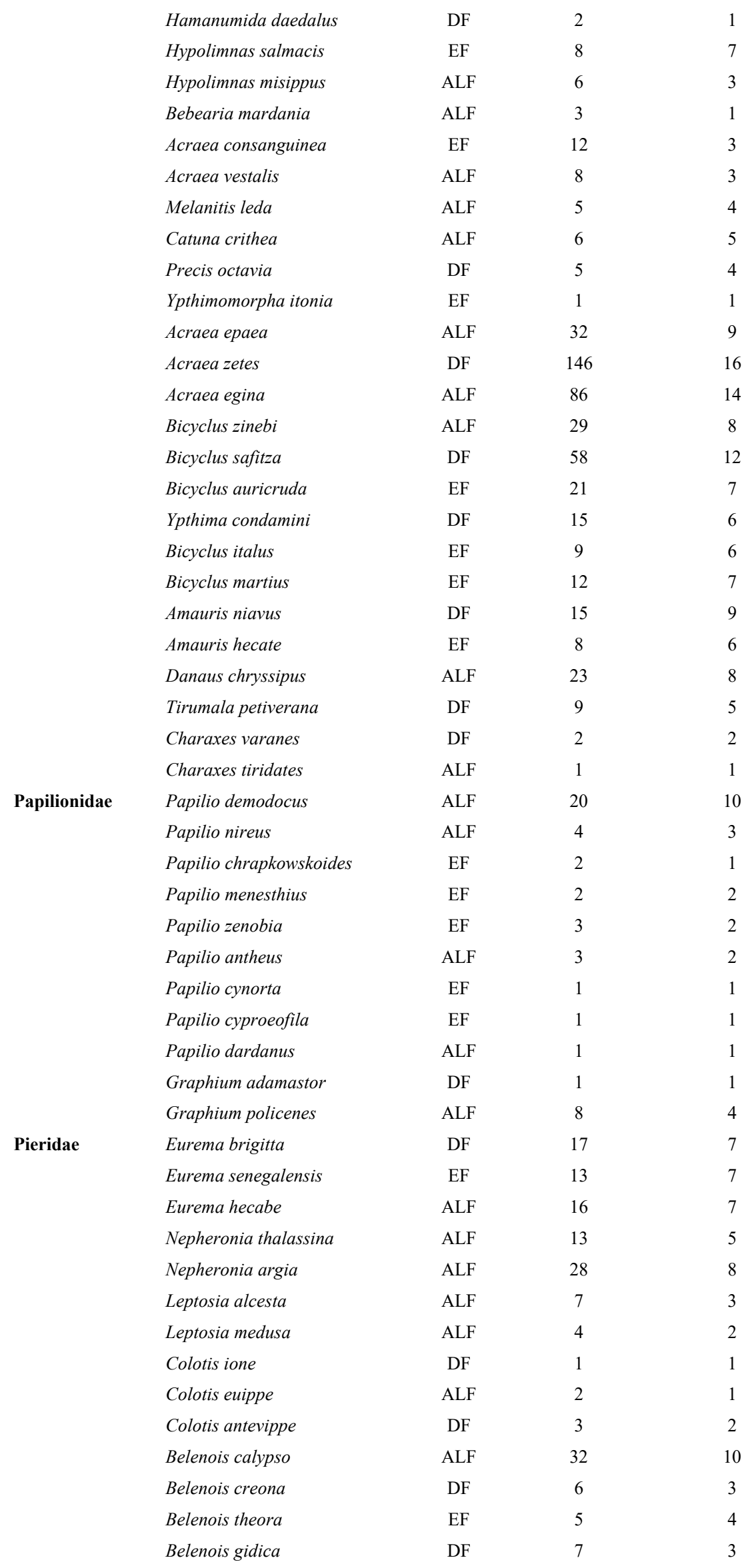




$\begin{array}{llccc} & \text { Belenois aurota } & \text { DF } & 5 & 4 \\ \text { Catopsilla florella } & \text { ALF } & 205 & 14 \\ \text { Mylothris chloris } & \text { ALF } & 30 & 8 \\ \text { Mylothris poppea } & \text { EF } & 6 & 5 \\ \text { Mylothris rhodope } & \text { ALF } & 6 & 4 \\ \text { Lycaenidae } & \text { Appias sylvia } & \text { ALF } & 5 & 4 \\ & \text { Tuxentius carana } & \text { ALF } & 5 & 4 \\ & \text { Euchrysops albistriata } & \text { DF } & 54 & 7 \\ & \text { Uranothauma falkensteini } & \text { ALF } & 7 & 5 \\ & \text { Hypolycaena liara } & \text { EF } & 44 & 12 \\ & \text { Hypolycaena hatita } & \text { EF } & 19 & 9 \\ & \text { Pyrrhiades lucagus } & \text { DF } & 38 & 5 \\ & \text { Osmodes adon } & \text { EF } & 8 & 4 \\ & \text { Osmodes adosus } & \text { EF } & 7 & 7 \\ & \text { Coliades forestan } & \text { ALF } & 8 & 6 \\ & \text { Tagiades flesus } & \text { ALF } & 19 & 5 \\ \text { Melphina malthina } & \text { EF } & 7 & 9\end{array}$

$\mathrm{EF}=$ species known to be associated with wet or moist evergreen forest, ALF $=$ species known to be generalists and hence can be found in any vegetation type, $\mathrm{DF}=$ species known to be associated with dry Guinea or Sudan Savannah vegetation.
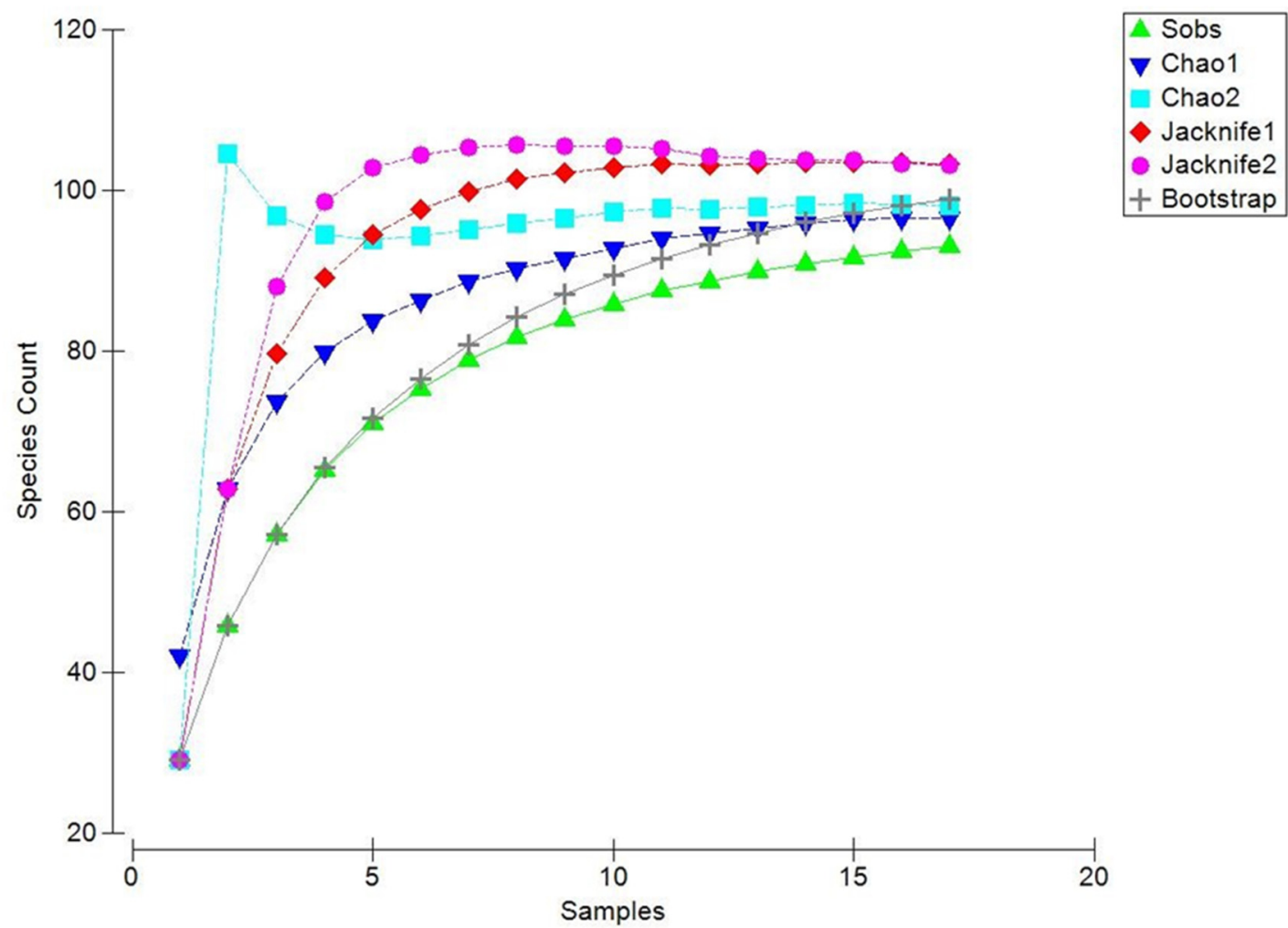

Figure 2. Species accumulation curve for Butterfly assemblages at Tarkwa Goldfields

The most abundant butterflies recorded were Catopsilia florella (Fabricius, 1775) with 205 individuals followed by Acraea zetes (Linnaeus, 1758) with 146 individuals. Species accumulation curves presented the cumulative number of species recorded and other species richness estimators as a function of the cumulative sampling effort (number of sampling sites) put into data collection. Species accumulation curves for butterfly assemblages showed the rate at which new species would have been encountered should sampling effort be increased. Together with 
the species richness estimators, an average of about 100 butterfly species (Chao $1=97$, Chao $2=98$, jackknife 1 and $2=103$, Bootstrap $=99$ ) was expected to occur within the concession, however, compared to the actual species richness (93) implies a good sampling effort for the area.

The 'Back of the Training School' of Tarkwa mine was the most important site for butterflies recording the highest species richness of 59 corroborated by the highest Margalef and Shannon Weiner indices of 11.33 and 3.71 respectively followed by 'TSF5' and the Old Weighing Bridge both with 49 species each. 'TSF5' recorded the highest number of individuals (abundance) of butterflies with 362 records. There was a generally high evenness of butterfly diversity in almost all sampling sites. 'TSF5' recorded the lowest evenness (J) of 0.78 across all study sites. On the other hand, 'TSF3/Abrewanko' Stretch of Vegetation recorded the lowest diversity and abundance of butterflies with 9 species and 11 individuals respectively, at the end of the sampling period.
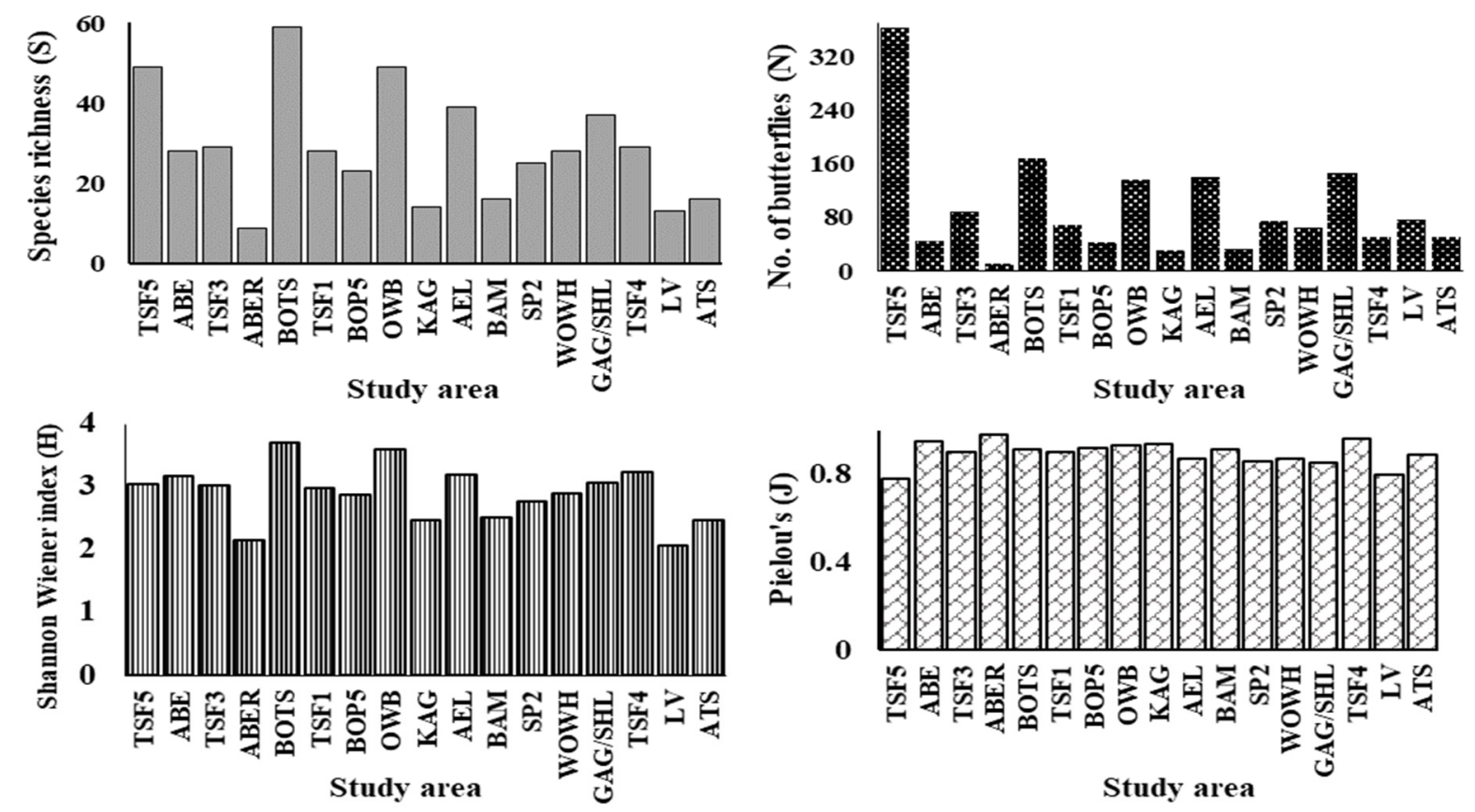

Figure 3. Mean diversity indices of butterfly species recorded on the Tarkwa Goldfields Concession ABE -

Abekoase, TSF3 - Nuamakrom/Auntie Gladys, ABER-TSF3/Aberewanko, BOTS - Back of training school, BOP5 - back of phase 5/Samanhu, OWB - Old weighing bridge, KAG - Kottraverchy Akontansi gap, AEL - AEL

Konttraverchy stretch, BAM - Bamboo dump, SP2 - SP2 assay lab, WOWH - Wetlands at old west heaps, GAG/SHL - south heaps GAG stretch, LV - South LV, ATS - Residential ATS

Ten butterfly species were recorded at one sampling site only and in most cases only one individual was encountered. 
Table 3. Butterflies unique only to a single site

\begin{tabular}{|c|c|c|c|c|c|}
\hline \multirow[b]{2}{*}{ Butterfly Species } & \multicolumn{5}{|c|}{ Sites within concession } \\
\hline & OWB & TSF4 & BOTS & WOWH & GAG/SHL \\
\hline Protogoniomorpha anacardii Linné 1758 & $\mathrm{X}$ & & & & \\
\hline Hamanumida daedalus Fabricius 1775 & & $\mathrm{X}$ & & & \\
\hline Bebearia mardania Fabricius 1793 & & & $\mathrm{X}$ & & \\
\hline Ypthimomorpha itonia Hewitson 1865 & & & & $\mathrm{X}$ & \\
\hline Papilio chrapkowskoides Koçak 1983 & & & $\mathrm{X}$ & & \\
\hline Papilio cynorta Fabricius 1793 & & & & & $\mathrm{X}$ \\
\hline Graphium adamastor Boisduval 1836 & & & & & $\mathrm{X}$ \\
\hline Papilio dardanus Brown 1776 & $\mathrm{X}$ & & & & \\
\hline Colotis euippe Linné 1758 & & & $\mathrm{X}$ & & \\
\hline Charaxes tiridates Cramer 1777 & & & $\mathrm{X}$ & & \\
\hline
\end{tabular}

OWB - Old weighing bridge; BOTS - Back of the training school; WOWH - Wetlands/Old west heap; GAG/SHL - GAG Boundary stretch/South heap leach facility.

Such a situation cannot be related to the rarity of the species since assessment of the absolute rarity of a butterfly species in such surveys is quite difficult because of their seasonality and localisation in distribution. Some species recorded are usually more distributed within vegetation zones other than that within which the concession falls (see Table 2). Among these are Graphium adamastor (Boisduval, 1836) and Ypthima condamini (Kielland, 1982), Bicyclus italus (Hewitson, 1865), Colotis ione (Godart, 1819) and Belenois gidica (Godart, 1819) (see Table 2).

There was a significant difference in group medians between diversity (richness) and abundance of butterfly species known to be associated with wet or moist evergreen forest (EF) on one hand and those known to be associated with dry Guinea or Sudan Savanah vegetation zones on the other hand (DF). There was also a significant difference in group median between species designated EF and generalist species (ALF).

Table 4. ANOVA for abundance and species richness of butterflies in TGM

\begin{tabular}{lll}
\hline Diversity indices & EF vs. DF (Kruskal-Wallis test) & EF vs. ALF (Kruskal-Wallis test) \\
\hline Abundance (N) & $\mathrm{H}=0.28, \mathrm{p}=0.59$ & $\mathrm{H}=2.16, \mathrm{p}=0.14$ \\
Species richness (S) & $\mathrm{H}=0.07, \mathrm{p}=0.80$ & $\mathrm{H}=1.13, \mathrm{p}=0.29$ \\
\hline
\end{tabular}

$\mathrm{EF}=$ species known to be associated with wet or moist evergreen forest, ALF $=$ species known to be generalists and hence can be found in any vegetation type, $\mathrm{DF}=$ species known to be associated with dry Guinea or Sudan Savannah vegetation.

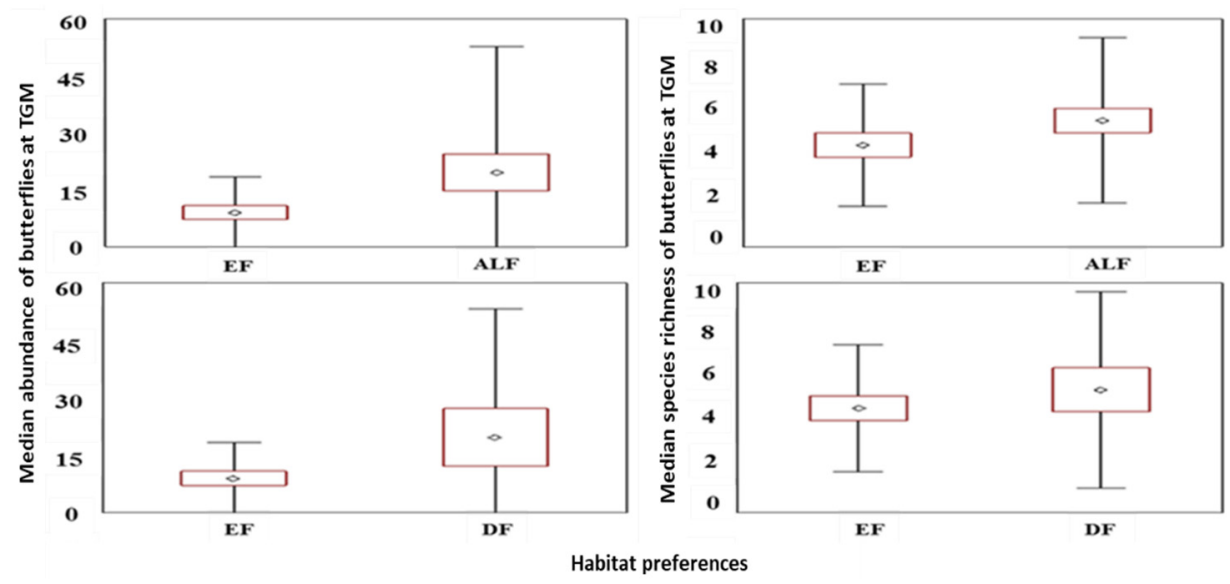

Figure 4. Comparison of group medians of butterfly groups DF, ALF and EF at TGM

$\mathrm{EF}=$ species known to be associated with wet or moist evergreen forest, $\mathrm{ALF}=$ species known to be generalists and hence can be found in any vegetation type, $\mathrm{DF}=$ species known to be associated with dry Guinea or Sudan Savannah vegetation. 


\section{Discussion}

The presence of species known to be associated with Sudan Savanna and other dry degraded forest zones shows changing vegetation or widespread degradation within the concession. In this study, such species and other more generalists species were more diverse and abundant than species strictly known to be associated with the known vegetation type within the zone in which the concession falls (refer to Fig. 3). Despite the high diversity of dry and Sudan Savannah indicator species within the concession, other species known to be associated with evergreen forested areas were also recorded. For instance, the high abundance of Neptis melicerta (Drury, 1773), Eurema senegalensis (Boisduval, 1836), Acraea consanguinea (Aurivillius, 1893), Bicyclus auricruda (Butler, 1868), Hypolycaena liara (Druce, 1890) and Hypolycaena hatita (Hewitson, 1865) is an indication that there is a level of satisfactory green vegetation and habitats within the area despite the high anthropogenic activities within the concession. For a successful evaluation and monitoring purpose, these species must be taken into consideration as indicator species as previously reported by (Fermon, Schulze, Waltert, \& Muhlenberg, 2001; Nijhout, 2003; Larsen, 1991, 1994, 2005, 2006).

\subsection{Butterfly Ecology in Relation to Forest Disturbances}

According to Larsen (2005), the huge presence of Papilio demodocus (Esper, 1798), P. nireus (Linnaeus, 1758), Junonia oenone (Linnaeus 1758) and $J$. terea (Druce, 1890) show widespread destruction and fragmentation of forest cover within the concession. This is because these species are known to be specialists of degraded habitats and open areas, hence few would ever be encounted within forests of good condition. At TGM mining activities have degraded the soil and vegetation and also polluted water bodies creating favourable habitats for these species to inhabit and populate (Losfeld, L'Huillier, Fogliani, Jaffré, \& Grison, 2015; Haule et al., 2016; Boiral \& HerasSaizarbitoria, 2017).

Danaus chrysippus (Linnaeus, 1758), Colotis euippe (Linnaeus, 1758) and J. oenone are species known to be colonisers of disturbed habitats in forest Zones. Large numbers of these species were also recorded in this study (Fermon, Schulze, Waltert, \& Muhlenberg, 2001; Larsen, 2005; Addo-Fordjour, Osei, \& Kpontsu, 2015; Khan \& Rastogi, 2015; Gandhi et al., 2017). Their presence in relatively high numbers within the concession is an indication of high levels of degradation of the original forest vegetation. According to Larsen (1994), C. euippe is also classified as an indicator for severely disturbed forest. $J$. oenone is a species typical of mining environments (Sagwe, Muya, \& Maranga, 2015; Agyemang, Acquah-Lamptey, Anderson, \& Kyerematen, 2015). The high presence of Acraea zetes throughout the study area is another indication of widespread degradation and a changing vegetation structure from a wet evergreen forested area to an open Savannah/Deciduous forest. The high occurrence of G. adamastor - a known indicator species of dry forests and transitional zones between forest and Guinea Savanna (Larsen, 2005) - maybe an indication of expansion of its range within the concession through widespread degradation.

Furthermore, the high population of Euchrysops albistriata (Capronnier, 1889) recorded, gives more evidence to indicate that the vegetation structure at TGM concession is degrading towards savanna vegetation type. This is because this species is a widely distributed savannah Lycinid but occurs in disturbed areas within forest zones (Larsen, 2005; Sáfián, 2014; Agyemang et al., 2015). Another species encountered in this survey was Protogoniomorpha anacardii (Linnaeus, 1758) which is found in tropical Africa and prefers drier forests and transition zones between forests and Guinea Savanna in West Africa (Larsen, 2005). Hamanumida daedalus (Fabricius 1775), popularly known as the Guinea fowl butterfly a species distributed throughout Africa and a known indicator for dry, rocky grassland with scattered bushes and trees (Woodhall, 2005) and a known coloniser of abandoned agricultural lands was recorded along sandy roads within the concession. The presence of, Charaxes tiridates (Cramer, 1777) which according to Larsen (2006), and Henning (1989), is a generalist could also mean vegetation within the concession is drifting towards homogenization in terms of diversity.

\section{Conclusions}

Even though this study recorded a very high butterfly diversity at the TGM operational site, the ecology of many of the butterfly species - especially the most abundant ones encountered, show that the operations of the mining company are having a detrimental effect on biodiversity. Vegetation cover and diversity play an important role in determining butterfly assemblage composition in an area. The presence of species such as of J. oenone, J. terea, $P$. nireus and $P$. demodocus and a relatively high diversity of species known to be associated with degraded forests and open areas compared with those known to be associated with wet or moist evergreen vegetation within which the concession falls is a clear indication of high forest degradation. Based on previous research from Larson (1994, 2005), very few of such species would ever be encountered within forest of good condition. The presence of species known to be associated with deep forest for instance, P. anacardii, P. zenobia (Fabricius, 1775), E. crockery 
(Butler, 1869), C. tiridates (Cramer, 1777) and H. salmacis (Drury, 1773), although less abundant, is welcome news and an indication that some forested areas within the TGM are still in good condition. These forest areas are likely serving as refugia for displaced species from areas where human activities like mining is having detrimental effect on biodiversity.

\subsection{Recommendation for Conservation and Policy Implications}

The Tarkwa Goldfields concession has rich and diverse butterfly community, but this characteristic high diversity and occupancy is highly influenced by land-use which also affects habitat quality. As has been used in this study and other previous studies, the dynamics of butterflies on the landscape, can be utilised for vegetation quality surveillance especially in an anthropogenically influenced one like the mining environment. Butterfly species preferences, especially those that do tolerate high disturbances opposed to those that do not, can be utilised in conservation planning schemes such as accessing the state of biodiversity before and after mining operations. Butterfly dynamics in the landscape can also be monitored within restoration projects at old and or abandoned mine sites.

Mining in general causes soil erosion and leaching of nutrients as well as contributing substantially to water pollution. These changes also affect vegetation type and structure and hence resource availability for animals in this area. Water bodies and important vegetation patches within the concession must therefore be well maintained and preserved for sustainability purposes. We recommend that patches of forested areas serving as refugia for displaced species as already being practiced by management of TGM be maintained. Such stretches of vegetation adjacent to the target operational sites must be left protected. More of such key stretches of vegetation targeted as refugia for displaced animals from destroyed habitats must be reserved for biodiversity conservation purposes. Extreme caution must also be exercised during mining operations to ensure that key habitats are not destroyed. This model of allowing stretches of vegetation patches to act as refugia for displaced animals can be adopted and practiced in other mine environments within Tarkwa and elsewhere in the country.

The widespread degradation of habitats and changing vegetation within the TGM warrants the need for a second look at the environmental compliance and regulations especially those related to mine operations as stipulated in the Environmental Assessment Regulations act of 1999 in Ghana. Although, there were visible signs that some areas were reserved for conservation purposes, there were widespread degradation within the concession. Another important regulation which can be used to further check the impact of mine activities within the concession and elsewhere is the enactment of laws to prevent the use of harmful chemicals which invariable end up as pollutants within the concession. Active restoration efforts can also be initiated in areas that have already been abandoned and no more in use for mining activities. Other restoration efforts such as the destruction of alien and invasive species - which have found new and conducive habitats as a result of mine activities - can improve the health of the ecosystem and habitats within the concession. Other regulatory factors missing in the operations of mine industries in Ghana are laws regarding sustainable use of resources especially natural resource management. Enacting laws regarding the sustainable mining practices and biodiversity protection has the potential of helping in the reduction of mine impact on the TGM concession, other mining activities in Ghana and the rest of the world.

\section{References}

Acquah-Lamptey, D., Kyerematen, R., \& Owusu, E. O. (2013). Using Odonates as markers of the environmental quality of water and its land related ecotone. International Journal of Biodiversity and Conservation, 5, 761769. https://doi.org/10.5897/IJBC2013.0600

Addo-Fordjour, P., Osei, B. A., \& Kpontsu, E. A. (2015). Butterfly community assemblages in relation to human disturbance in a tropical upland forest in Ghana, and implications for conservation. Journal of Insect Biodiversity, 3, 1-18. http://dx.doi.org/10.12976/jib/2015.3.6

Adu-Acheampong, S., Bazelet, C. S., \& Samways, M. J. (2016). Extent to which an agricultural mosaic supports endemic species-rich grasshopper assemblages in the Cape Floristic Region biodiversity hotspot. Agric. Ecosyst. Environ, 227, 52-60. https://doi.org/10.1016/j.agee.2016.04.019

Adu-Acheampong, S., Samways, M. J., Landmann, T., Kyerematen, R., Minkah, R., Mukundamago, M., \& Moshobane, C. M. (2017). Endemic grasshopper species distribution in an agro-natural landscape of the Cape Floristic Region, South Africa. Ecological Engineering, 105, 133-140. https:// doi.org/10.1016/j.ecoleng. 2017.04.037

Agyemang, D. O., Acquah-Lamptey, D., Anderson, R. S., \& Kyerematen, R. (2015). First records of butterfly diversity on two remote Islands on the Volta Lake of Ghana, the largest reservoir by total surface area in the world. Research in Zoology, 5, 32-37. https://doi.org/10.5923/j.zoology.20150502.02 
Akabzaa, T., \& Darimani, A. (2001). Impact of mining sector investment in Ghana: A study of the Tarkwa mining region. Third World Network.

Amankwah, R. K., \& Anim-Sackey, C. (2003). Strategies for sustainable development of the small-scale gold and diamond mining industry of Ghana. Research Policy, 29, 131-138. https://doi.org/10. 1016/j.resourpol.2004. 07.002

Aryee, B. N. (2001). Ghana's mining sector: its contribution to the national economy. Resources Policy, 27, 6175. https://doi.org/10.1016/S0301-4207(00)00042-8

Attuquayefio, D., Kyerematen, R., Owusu, E. H., Oteng-Appau, R., Asamoah, A., \& Ekpe, P. K. (2007). Biodiversity survey of the operational areas of Abosso Goldfields Limited (AGL) Damang. Ghana Wildlife Society. Retrieved from https://www.researchgate.net/profile/RosinaKyerematen/publication/260103103 Terrestrial_Insects/links/00b4952f 8f2a9f 39e20 00000/Terrestrial-Insects.pdf

Attuquayefio, D. K., Owusu, E. H., \& Ofori, B. Y. (2017). Impact of mining and forest regeneration on small mammal biodiversity in the Western Region of Ghana. Environmental monitoring and assessment, $189,237$. https://doi.org/10.1007/s1066

Bakowski, M., \& Doku-Marfo, E. (2009). A Rapid biodiversity assessment of the Ajenjua Bepo and Mamang River Forest Reserves. Conservation International, 30, 33.

Bloch, R., \& Owusu, G. (2012). Linkages in Ghana's gold mining industry: Challenging the enclave thesis. Resources Policy, 37, 434-442. https://doi.org/10.1016/j.resourpol.2012.06.004

Boiral, O., \& Heras-Saizarbitoria, I. (2017). Corporate commitment to biodiversity in mining and forestry: Identifying drivers from GRI reports. Journal of Cleaner Production, 162, 153-161. https://doi.org/10.1016/ j.jclepro.2017.06.037

Bonfantti, D., Di Mare, R. A., \& Giovenardi, R. (2009). Butterflies (Lepidoptera: Papilionoidea and Hesperioidea) from two forest fragments in northern Rio Grande do Sul, Brazil. Check List, 5, 819-829. http://dx. doi.org/10.15560/5.4.819

Bossart, J. L., \& Antwi, J. B. (2013). Species-specific traits predict genetic structure but not genetic diversity of three fragmented Afrotropical forest butterfly species. Conservation genetics, 14, 511-528. https://doi.org/10.1007/s10592-012-0436-9

Bossart, J. L., \& Antwi, J. B. (2016). Limited erosion of genetic and species diversity from small forest patches: Sacred forest groves in an Afrotropical biodiversity hotspot have high conservation value for butterflies. Biological Conservation, 198, 122-134. https://doi.org/10.1016/j.biocon.2016.03.029

Brosse, S., Grenouillet, G., Gevrey, M., Khazraie, K., \& Tudesque, L. (2011). Small-scale gold mining erodes fish assemblage structure in small neotropical streams. Biodiversity and Conservation, 20, 1013-1026. https://doi.org/10.1007/s10531-011-0011-6

Carcasson, R. H. (1981). Collins hand guide to the butterflies of Africa. William Collins Sons and Co. Ltd. UK. https://doi.org/10.1017/S0030605300029550

Carmichael, G. R., Streets, D. G., Calori, G., Amann, M., Jacobson, M. Z., Hansen, J., \& Ueda, H. (2002). Changing trends in sulfur emissions in Asia: implications for acid deposition, air pollution, and climate. Environ. Sci. Technol., 36, 4707-4713. https://doi.org/10.1021/es011509c

Carter, D. (1992). Eyewitness handbooks of butterflies and moths. London: Dorling Kindersley.

Chinery, M. (1995). Butterflies and moths: photo guide. Harper Collins - Publishers.

Clarke, K. R., \& Gorley, R. N. (2006). PRIMER v6: User manual/tutorial. PRIMER-E, Plymouth UK.

Clarke, K. R., \& Warwick, R. M. (2001). Change in marine communities: an approach to statistical analysis and interpretation (2nd ed.). PRIMER-E, Plymouth, UK.

Coelho, M. S., Fernandes, G. W., Santos, J. C., \& Delabie, J. H. C., (2009). Ants (Hymenoptera: Formicidae) as bioindicators of land restoration in a Brazilian Atlantic forest fragment. Sociobiology, 54, 51.

Edwards, D. P., Sloan, S., Weng, L., Dirks, P., Sayer, J., \& Laurance, W. F. (2014). Mining and the African environment. Conservation Letters, 7, 302-311. https://doi.org/10.1111/conl.12076

Fermon, H., Schulze, C. H., Waltert, M., \& Muhlenberg, M. (2001). The butterfly fauna of the Noyau Central, Lama Forest (Republic of Benin), with notes on its ecological composition and geographic distribution. African Entomology, 9, 177-185. http://hdl.handle.net/10520/EJC32951 
Fleishman, E., \& Murphy, D. D. (2009). A realistic assessment of the indicator potential of butterflies and other charismatic taxonomic groups. Conservation Biology, 23, 1109-1116. https://doi.org/10.1111/j.1523-1739. 2009.01246.x

Fleishman, E., Yen, J. D., Thomson, J. R., Mac Nally, R., Dobkin, D. S., \& Leu, M. (2018). Identifying spatially and temporally transferrable surrogate measures of species richness. Ecological Indicators, 84, 470-478. https://doi.org/10.1016/j.ecolind.2017.09.020

Gandhi, N., Patel, C., \& Padate, G. (2017). Butterfly diversity around an irrigation reservoir in the semi-arid zone of central Gujarat, India: A consideration for conservation management. Int. J. Adv. Res. Biol. Sci., 4, 43-53

Hall, J. B., \& Swaine, M. D., (1976). Classification and ecology of closed canopy forests in Ghana. J. Ecol., 614, 913-951.

Hao, S., Wang, S., Cease, A., \& Kang, L. (2015). Landscape level patterns of grasshopper communities in Inner Mongolia: interactive effects of livestock grazing and a precipitation gradient. Landsc. Ecol., 30, 1657-1668. https://doi.org/10.1007/s1098

Haule, H., Ringo, J., Luvinga, K., Kawonga, S., Mayengo, G., \& Morsardi, L. (2016). Effects of Limestone Mining on Deforestation and Land Degradation in Mbeya Region, Tanzania. Int. J. Modern Soc. Sci., 5, $117-132$.

Hawksworth, D. L., \& Bull, A. T. (2007). Biodiversity and conservation in Europe. Springer Netherlands.

Henning, S. F. (1989). The Charaxinae Butterflies of Africa. Johannesburg: Aloe Books.

Hill, T., \& Lewicki, P. (2007). Statistics: methods and applications. StatSoft, Tulsa, OK.

Hilson, G. (2002). An overview of land use conflicts in mining communities. Land use policy, 19 , 65-73. https://doi.org/10.1016/S0264-8377(01)00043-6

Hilson, G., Hilson, C. J., \& Pardie, S. (2007). Improving awareness of mercury pollution in small-scale gold mining communities: challenges and ways forward in rural Ghana. Environ. Res., 103, 275-287. https://doi.org/10.1016/j.envres.2006.09.010

Hiyama, A., Taira, W., Sakauchi, K., \& Otaki, J. M., (2018). Sampling efficiency of the pale grass blue butterfly Zizeeria maha (Lepidoptera: Lycaenidae): A versatile indicator species for environmental risk assessment in Japan. Journal of Asia-Pacific Entomology, 21, 609-615. https://doi.org/10.1016/j.aspen.2018.03.010

Jones, J. E. (2013). Fish and river pollution. Butterworth and Co. London

Khan, S. R. \& Rastogi, N. (2015). Impact of mining activity on butterfly diversity and community composition. Journal of Entomology and Zoology Studies, 3, 178-185

Kitula, A. G. N. (2006). The environmental and socio-economic impacts of mining on local livelihoods in Tanzania: A case study of Geita District. Journal of cleaner production, 14, 405-414. https://doi.org/10.1016/ j.jclepro. 2004.01.012

Kyerematen, R., Acquah-Lamptey, D., Owusu. E. H., Anderson, R. S., \& Ntiamoa-Baidu, Y. (2014b). Insect Diversity of the Muni-Pomadze Ramsar Site: An important site for biodiversity conservation in Ghana. Journal of Insects, 2014, 11. http://dx.doi.org/10.1155/2014/985684

Kyerematen, R., Akuamoah-Boateng, A., Acquah-Lamptey, D., \& Anderson, R. S. (2014c). Land use type affects butterfly diversity: a case study of the University of Ghana, main campus, Legon. J. Biodivers. Environ. Sci., 5, 205-214.

Kyerematen, R., Kaiwa, F., Acquah-Lamptey, D., Adu-Acheampong, S., Andersen, R.S. (2018). Butterfly Assemblages of Two Wetlands: Response of Biodiversity to Different Environmental Stressors in Sierra Leone. Open Journal of Ecology, 8:379-395. https://doi.org/10.4236/oje.2018.87023

Kyerematen, R., Owusu, E. H., Acquah-Lamptey, D., Anderson, R. S., \& Ntiamoa-Baidu, Y. (2014a). Species composition and diversity of insects of the Kogyae Strict Nature Reserve in Ghana. Open Ecol. J., 4, 1061 1079. http://dx.doi.org/10.4236/oje.2014.417087

Larsen, T. B. (1991). The butterflies of Kenya and their Natural History. Oxford University Press, Oxford.

Larsen, T. B. (1994). The butterflies of Ghana-their implications for conservation and sustainable use. Report to IUCN and Dept. of Game and Wildlife, Ghana.

Larsen, T. B. (1995). Butterflies in Kakum National Park, Ghana. Part 1: Papilionidae, Pieridae and Lycaenidae. Bulletin of the Amateur Entomological Society, 54, 3-8. 
Larsen, T. B. (1995). Butterflies in Kakum National Park, Ghana. Part 2: Nymphalidae, Hesperiidae. Bulletin of the Amateur Entomological Society, 54, 43-46.

Larsen, T. B. (2001). The butterflies of Ankasa/Nini-Suhien and Bia protected area systems in western Ghana. Protected areas development programme. Western Region Ghana. ULG Northumbrian Ltd.

Larsen, T. B. (2005). Rapid assessment of butterflies of Draw River, Boi-Tano and Krokosua Hills. In J. McCullough, J. Decher, \& D. Guba Kpelle (Eds.), A biological assessment of the terrestrial ecosystems of the Draw River, Bio-Tano, Tano Nimiri and Krokosua Hills forest reserves.

Larsen, T. B. (2006). The Ghana butterfly fauna and its contribution to the objectives of the protected areas system. Forestry Commission (Wildlife Division). Wildlife Division Support Project Report, 63, 122.

Lee Foote, A., \& Rice Hornung, C. L. (2005). Odonates as biological indicators of grazing effects on Canadian prairie wetlands. Ecological Entomology, 30, 273-283. https://doi.org/10.1111/j.0307-6946.2005.00701.x

Lenzen, M., Murray, S. A., Korte, B., \& Dey, C. J. (2003). Environmental impact assessment including indirect effects-a case study using input-output analysis. Environmental Impact Assessment Review, 23, 263-282. https://doi.org/10.1016/S0195-9255(02)00104-X

Lindenmayer, D. B., \& Likens, G. E. (2011). Direct measurement versus surrogate indicator species for evaluating environmental change and biodiversity loss. Ecosystems, 14, 47-59. https://doi.org/10.1007/s10021 -0109394-6

Losfeld, G., L’Huillier, L., Fogliani, B., Jaffré, T., \& Grison, C. (2015). Mining in New Caledonia: environmental stakes and restoration opportunities. Environmental Science and Pollution Research, 22, 5592-5607. https://doi.org/10.1007/s11356-014-3358-x

Maes, D., \& Van Dyck, H. (2005). Habitat quality and biodiversity indicator performances of a threatened butterfly versus a multispecies group for wet heathlands in Belgium. Biological conservation, 123, 177-187. https://doi.org/10.1016/j.biocon.2004.11.005

Magurran, A. E. (2004). Measuring biological diversity. Blackwell Science Ltd., Oxford.

Majer, J. D., Orabi, G., \& Bisevac, L. (2007). Ants (Hymenoptera: Formicidae) pass the bioindicator scorecard. Myrmecol. News, 10, 69-76.

Marshall, J. C., Steward, A. L., \& Harch, B. D. (2006). Taxonomic resolution and quantification of freshwater macroinvertebrate samples from an Australian dryland river: The benefits and costs of using species abundance data. Hydrobiologia, 572, 171-194. https://doi.org/10.1007/s10750-005-9007-0

Moreno, C. E., Sánchez-Rojas, G., Pineda, E., \& Escobar, F. (2007). Shortcuts for biodiversity evaluation: a review of terminology and recommendations for the use of target groups, bioindicators and surrogates. International Journal of Environment and Health, 1, 71-86. https://doi.org/10.1504/ IJENVH.2007.012225

Nganso, B. T., Kyerematen, R., \& Obeng-Ofori, D. (2012). Diversity and abundance of butterfly species in the Abiriw and Odumante sacred groves in the Eastern Region of Ghana. Res. Zoo., 2, 38-46. https://doi.org/10. 5923/j.zoology.20120205.01

Nijhout, H. F. (2003). Polymorphic mimicry in Papilio dardanus: mosaic dominance, big effects and origins. Evol. Dev., 5, 579-592. https://doi.org/10.1046/j.1525-142X.2003.03063.x

Pollard, E., Woiwod, I. P., Greatorex-Davies, J. N., Yates, T. J., \& Welch, R. C. (1998). The spread of coarse grasses and changes in numbers of Lepidoptera in a woodland nature reserve. Biological Conservation, 84, 17-24. https://doi.org/10.1016/S0006-3207(97)00090-6

Pullin, A. S. (1996). Restoration of butterfly populations in Britain. Restoration Ecology, 4, 71-81. https://doi.org/ 10.1111/j.1526-100X.1996.tb00109.x

Raina, S. K., Chauhan, T. P. S., Tayal, M. K., Pande, R. K., \& Mohan, R. (2011). Multiple silkworm cocoon cropping in jammu division. Proceedings of the Workshop on Recent Trends in Development of Sericulture in Jammu and Kashmir, Jammu and Kashmir, India 63-67.

Sáfián, S. (2014). Butterflies of the Nimba Mountains, Liberia Report on the butterfly surveys (2013-2014) for ArcelorMittal, Liberia. Retrieved from http://liberia.arcelormittal.com/ /media/Files/A/ArcelorMittal Liberia/reports-and-presentations/butterflies-of-the-nimba-mountains-liberias-safian-dec-2014.pdf 
Sagwe, R. N., Muya, S. M., \& Maranga, R. (2015). Effects of land use patterns on the diversity and conservation status of butterflies in Kisii highlands, Kenya. Journal of Insect Conservation, 19, 1119-1127. https://doi.org /10.1007/s10841-015-9826-X

Schueler, V., Kuemmerle, T., \& Schröder, H. (2011). Impacts of surface gold mining on land use systems in Western Ghana. Ambio, 40, 528-539. https://doi.org/10.1007/s13280-011-0141-9

StatSoft Incorporated. (2013). Electronic statistics textbook. Tulsa, OK: StatSoft. Retrieved February 5, 2015, from http://www.statsoft.com/textbook

Thomas, C. D., \& Harrison, S. (1992). Spatial dynamics of a patchily distributed butterfly species. Journal of Animal Ecology, 61, 437-446. https://doi.org/10.2307/5334

Van Dyck, H., Van Strien, A. J., Maes, D., \& Van Swaay, C. A. (2009). Declines in common, widespread butterflies in a landscape under intense human use. Conservation Biology, 23, 957-965.

Weisser, W. W., \& Siemann, E. (2008). The various effects of insects on ecosystem functioning. In Insects and ecosystem function (pp. 3-24). Springer, Berlin, Heidelberg.

Wiens, J. A., Hayward, G. D., Holthausen, R. S., \& Wisdom, M. J. (2008). Using surrogate species and groups for conservation planning and management. AIBS Bulletin, 58, 241-252. https://doi.org/10.16 41/B580310

Wilson, E. O. (1987). Causes of ecological success: the case of the ants. Journal of Animal Ecology, 56, 1-9. https:// doi.org/10.2307/4795

Woodhall, S. (2005). Field guide to butterflies of South Africa. Struik Publishers.

Yabe, J., Ishizuka, M., \& Umemura, T. (2010). Current levels of heavy metal pollution in Africa. Journal of Veterinary Medical Science, 72, 1257-1263. https://doi.org/10.1292/jvms.10-0058

Yelpaala, K., \& Ali, S. H. (2005). Multiple scales of diamond mining in Akwatia, Ghana: addressing environmental and human development impact. Resources Policy, 30, 145-155. https://doi.org/10.1016/j. resourpol.2005.08.001

\section{Copyrights}

Copyright for this article is retained by the author(s), with first publication rights granted to the journal.

This is an open-access article distributed under the terms and conditions of the Creative Commons Attribution license (http://creativecommons.org/licenses/by/4.0/). 